\title{
Effects of food consumption and temperature on growth rate and biochemical-based indicators of growth in early juvenile Atlantic cod Gadus morhua and haddock Melanogrammus aeglefinus
}

\author{
Myron A. Peck ${ }^{1,5, *}$, Lawrence J. Buckley ${ }^{2}$, Elaine M. Caldarone ${ }^{3}$, David A. Bengtson ${ }^{4}$ \\ ${ }^{1}$ Graduate School of Oceanography, University of Rhode Island, South Ferry Road, Narragansett, Rhode Island 02882, USA \\ ${ }^{2}$ URI/NOAA CMER Program, Graduate School of Oceanography, University of Rhode Island, Narragansett, \\ Rhode Island 02882, USA \\ ${ }^{3}$ National Oceanic and Atmospheric Administration, National Marine Fisheries Service, Narragansett Laboratory, \\ 28 Tarzwell Drive, Narragansett, Rhode Island 02882, USA \\ ${ }^{4}$ Department of Fisheries, Animal, and Veterinary Science, University of Rhode Island, Kingston, Rhode Island 02881, USA \\ ${ }^{5}$ Present address: Institute of Hydrobiology and Fisheries Research, University of Hamburg, Olbersweg 24, \\ 22767 Hamburg, Germany
}

\begin{abstract}
The relationship between the somatic growth rate $(G)$ and feeding level (unfed, intermediate, and maximum rations) of age-0 juvenile cod Gadus morhua and haddock Melanogrammus aeglefinus was quantified at different temperatures. Laboratory trials were conducted using 2 sizeclasses of cod (3.6 to $5.6 \mathrm{~cm}$ standard length [SL], and 8.1 to $12.4 \mathrm{~cm} \mathrm{SL}$ ) at $5,8,12$, and $15^{\circ} \mathrm{C}$, and 1 size-class of haddock ( 6.0 to $9.6 \mathrm{~cm} \mathrm{SL})$ at 8 and $12^{\circ} \mathrm{C}$. The shape of the growth-feeding relationship was well described by a 3-parameter asymptotic function for cod and by a linear function for haddock $\left(\mathrm{R}^{2}\right.$ range $=0.837$ to 0.966$)$. The growth rate and scope for growth were maximum at $12^{\circ} \mathrm{C}$, whereas growth efficiency was greatest (26.0 to $32.2 \%$ ) at temperatures between 5 and $8^{\circ} \mathrm{C}$. Juvenile cod held at $15^{\circ} \mathrm{C}$ exhibited reduced rates and efficiencies of somatic growth compared to fish at other temperatures. Biochemical-based growth indicators for age-0 juveniles were calibrated from measurements of the amounts of RNA, DNA, and protein in white muscle samples. A multiple linear regression using RNA:DNA and temperature as independent variables explained a significant portion of the variability observed in $G$ of juvenile $\operatorname{cod}\left(\mathrm{R}^{2}=0.716\right)$ and haddock $\left(\mathrm{R}^{2}=0.637\right)$. This relationship may be useful in estimating recent growth of age-0 juvenile cod and haddock in the field.
\end{abstract}

KEY WORDS: Age-0 juvenile $\cdot$ Cod $\cdot$ Haddock $\cdot$ Feeding $\cdot$ Growth $\cdot$ RNA:DNA Resale or republication not permitted without written consent of the publisher

\section{INTRODUCTION}

Since the 1960s, low spawning stock numbers and variable year-class success in Atlantic cod Gadus morhua, haddock Melanogrammus aeglefinus and other groundfish species on Georges Bank have led to extensive research efforts aimed at understanding how biotic and abiotic factors affect the growth and survival of these fish. Field data collected for cod and haddock in the NW Atlantic suggest that factors operating dur- ing the early juvenile period influence year-class success in some years (Campana et al. 1989, Werner et al. 1999). Of special importance is the protracted habitat transition from the pelagic to demersal environment (settlement) which occurs in young-of-the-year (YOY) juveniles of both species at $\sim 4$ to $8 \mathrm{~cm}$ standard length (SL) (Lough \& Potter 1993). The somatic growth rate of fish (age $90 \mathrm{~d}$ ) shortly after this year-0 juvenile settlement phase has been positively correlated to year-class success in Atlantic cod (Campana 1996). However, dif- 
ficulties both in the successful rearing of juvenile gadids in the laboratory, and the live capture and transport from the wild, have hampered efforts to evaluate the environmental factors that affect growth during this early juvenile period. Recent advances in the culture of cod and haddock now enable us to study the factors affecting growth and survival of year- 0 juveniles of both species in greater detail.

Quantifying the relationship between rates of feeding and growth in an organism can provide considerable ecological insight. The growth-feeding relationship of juveniles of a variety of marine fish species has been studied via laboratory trials (e.g. Elliott 1975b, Fonds et al. 1992, Malloy \& Targett 1994, Buckel et al. 1995) in an effort to increase the efficiency of aquaculture and to address ecological questions. Of particular ecological relevance are data collected on (1) rates of food consumption required for maintenance of existing tissues $\left(C_{\text {main }}\right),(2)$ maximum consumption rates $\left(C_{\max }\right)$, (3) gross growth efficiency (GGE) (Brett \& Groves 1979) and (4) optimal temperatures for growth.

Although previous studies have evaluated the growth-feeding relationship in large juvenile and adult cod (e.g. Edwards et al. 1972, Jones 1978, Jones \& Hislop 1978, Hawkins et al. 1985), relatively little research has been conducted on this relationship in age- 0 juvenile cod. Our understanding of the growth-feeding relationship in age- 0 juvenile cod has been advanced by studies conducted at cold temperatures (Brown et al. 1989) and maximal feeding levels (Otterlei 2000, Purchase \& Brown 2000). Extending these analyses to include a wider range in both temperatures and feeding levels would provide additional ecologically relevant data, since age-0 juvenile cod are found over a wide temperature range (Fahay et al. 1999) and feeding may be sub-maximal due to limited prey resources (Buckley et al. unpubl. data) or foraging limits imposed by competition (Tupper \& Boutilier 1995) and/or predation risk (Clark \& Green 1990). To our knowledge, only 1 study (Jones 1978) has provided information on the growth-feeding relationship of haddock.

Gaining reliable field estimates of growth rate and condition of an organism is an essential step toward understanding the factors that influence growth and survival. In early life stages of marine fish, biochemicalbased indicators of growth, including measuring the quantities and/or ratios of nucleic acids (RNA and DNA) and protein in the whole body or specific tissues (e.g. Write \& Martin 1985, Malloy \& Targett 1994, Rooker \& Holt 1996, Kuropat et al. 2002), have been used to generate field growth estimates. These indicators have been successfully applied to field-caught cod and haddock larvae (Buckley 1984) and have been measured in larger juvenile cod (Foster et al. 1993) but have not been calibrated for age-0 juvenile cod or haddock.
The primary objective of the present research was to quantify the relationship between rates of feeding and growth in age-0 juvenile cod and haddock. We conducted growth-feeding trials over a wide range of temperatures and feeding levels in an effort to understand how these factors influence growth and perhaps survival of both species during the age-0 period in the field. Specifically, we measured the growth rates of juvenile cod at $5,8,12$, and $15^{\circ} \mathrm{C}$, and haddock at 8 and $12^{\circ} \mathrm{C}$ that were either (a) unfed, (b) fed intermediate rations, or (c) fed maximum rations. A second research objective was to measure white muscle RNA, DNA, and protein in fish from these laboratory trials in an effort to evaluate and calibrate biochemical-based indicators of growth for future use on field-caught age-0 juveniles.

\section{MATERIALS AND METHODS}

Laboratory fish rearing. Several batches of juvenile Atlantic cod and haddock ( 2 to $3 \mathrm{mo}, 2$ to $3 \mathrm{~cm} \mathrm{SL}$ ) were obtained from an aquaculture research center (University of Maine, Orono, ME) and transported to the National Oceanic and Atmospheric Administration, National Marine Fisheries Service (NOAA NMFS), Narragansett Laboratory. Juvenile haddock were the progeny of wild-caught adult broodstock spawned in captivity at either of 2 locations, the NOAA NMFS Narragansett Aquarium (fish from Great South Channel off the coast of Cape Cod, Massachusetts, USA) or Memorial University, Newfoundland, Canada (Nova Scotia and Newfoundland fish). Juvenile cod were the progeny of NOAA NMFS broodstock. Once transported to our laboratory, the juveniles were held in temperature-controlled, flow-through, circular tanks (91.4 and $121.9 \mathrm{~cm}$ diameter) receiving filtered $(20 \mu \mathrm{m})$ Narragansett Bay seawater (1 to $31 \mathrm{~min}^{-1}$ ). The salinity was 29 to $32 \%$ and light levels were 0.5 to $1.0 \mu \mathrm{mol} \mathrm{m} \mathrm{m}^{-2}$ $\mathrm{s}^{-1}$. Fish were fed an artificial diet (BioKyowa ${ }^{\mathrm{TM}}, \mathrm{C}-500$, or $\mathrm{C}-1000 \mu \mathrm{m}$ pellet) 1 to 3 times daily, depending upon fish size, prior to experimentation.

Growth-feeding trials. Fifteen growth-feeding trials were conducted, 5 using smaller $(\sim 4.5 \mathrm{~cm}$ SL) juvenile $\operatorname{cod}\left(\operatorname{cod}_{\mathrm{S}}, \mathrm{n}=174\right), 6$ trials using larger $(\sim 9.0 \mathrm{~cm} \mathrm{SL})$ juvenile $\operatorname{cod}\left(\operatorname{cod}_{\mathrm{L}}, \mathrm{n}=225\right)$, and 4 using $(\sim 7.0 \mathrm{~cm}$ SL) juvenile haddock $(n=135)$. Prior to a trial, fish were acclimated to the experimental temperature $(5,8,12$, or $15^{\circ} \mathrm{C}$ ) for at least $10 \mathrm{~d}$ (Table 1). Trials lasted from 8 to $13 \mathrm{~d}$ (depending upon fish size and water temperature) and contained 6 to 17 tanks (10 l semi-static, 3/4 water replacement $\mathrm{d}^{-1}$ ) with 3 randomly selected juvenile fish in each tank. Preliminary trials indicated that isolated fish had reduced food consumption compared to groups of 2 or 3 fish. In each trial, 2 replicate tanks were main- 
tained at each of 3 feeding rates: (1) no food (unfed), (2) intermediate rations, and (3) maximum rations. A total of 4 intermediate rations $(\sim 1.5,3.0,5.0$, and $7.5 \%$ fish dry body weight) was used, with 1 to 3 intermediate ration levels included in each trial. Fed fish were provided pre-weighed rations of an artificial diet (BioKyowa $^{\mathrm{TM}} \mathrm{C}-1000 \mu \mathrm{m}$ pellet), over the course of at least 2 daily feedings. To calculate the weight of food consumed, uneaten pellets were collected on each day, counted, and their weight estimated (1 pellet $=0.91 \pm$ $0.02 \mathrm{mg}$ ). Due to the large difference between the percentage of water in the food $(4.7 \%, \mathrm{n}=10)$ and the fish (78.3\% cod, $81.7 \%$ haddock, Peck et al. 2003, unpubl. data), food consumption rate by fish was expressed on a dry weight basis with fish wet weight converted to dry weight using equations in Peck et al. (2003, unpubl. data). The BioKyowa ${ }^{\mathrm{TM}}$ diet used in this study was $55 \%$ protein, $10 \%$ fat, $4 \%$ fiber, and $17 \%$ ash (manufacturer's data). The energy content of the artificial diet was $20.82 \pm 0.31$ (SE) Joules (mg dry weight $)^{-1}(\mathrm{n}=15$, Gentry, Phillipson Micro-bomb calorimeter).

At the beginning and end of each trial, fish were anaesthetized (MS 222, $0.7 \mathrm{mg} \mathrm{l}^{-1}$ ) and the wet weight of each fish was measured $( \pm 0.01 \mathrm{~g}$, Sartorius LC $2200 \mathrm{~S}$ electronic balance). At the end of each trial, fish SL was measured ( $\pm 0.1 \mathrm{~mm}$, Measy \#5921 caliper). At the end of 10 of the trials (Table 1), a white muscle sample was dissected from the dorsal region anterior to the first dorsal fin of each fish and stored at $-80^{\circ} \mathrm{C}$ until biochemical analyses were performed. A total of 333 muscle samples were collected and analyzed, 207 from cod and 126 from haddock.

Fish growth. The specific growth rate $\left(G, \% \mathrm{~d}^{-1}\right)$ was calculated based on the formula:

$$
G=100\left(\mathrm{e}^{g}-1\right)
$$

where $g=$ instantaneous growth coefficient equal to:

$$
g=\left(\operatorname{Ln} W_{t}-\operatorname{Ln} W_{0}\right) / t
$$

where $W_{t}$ and $W_{0}$ equal the final and initial mean wet weight of the 3 fish within a replicate tank and $t=$ time (d) between measurements. Gross growth efficiency (GGE) was calculated as:

$$
\mathrm{GGE}=100(G / C)
$$

where $C=$ food consumption rate (\% dry body weight fish $^{-1} \mathrm{~d}^{-1}$ ). In our calculations of GGE using Eq. (3), we used predicted values for $G$ (determined from regression analyses performed on growth-feeding data) and observed values for $C$. Observed $C\left(\% \mathrm{~d}^{-1}\right)$ was the mean value of daily consumption estimates equal to the dry weight of food consumed in a day, divided by total dry weight of fish in the tank on that day (initial weight + daily increase determined from Eq. 1) multiplied by 100 .
Table 1. Gadus morhua and Melanogrammus aeglefinus. Summary data for laboratory growth-feeding trials conducted using age-0 juvenile Atlantic cod (2 size groups, $\operatorname{cod}_{\mathrm{S}}$ and $\left.\operatorname{cod}_{\mathrm{L}}\right)$, and haddock at different temperatures. Mean $\pm \mathrm{SE}$ final size (wet weight [wet wt] and standard length [SL]) of fish used in each trial are provided. Days = trial duration; $\mathrm{DM}=$ dissection of muscle for biochemical analyses; $\mathrm{Y}=$ yes; $\mathrm{N}=$ No. $\mathrm{n}=3$ fish per tank

\begin{tabular}{|cccccc|}
\hline \multicolumn{5}{|c|}{ Growth-feeding trial } & \multicolumn{3}{c|}{ Age-0 juvenile fish final size } \\
Species (ID) & Tanks & Days & DM & Wet wt (g) & SL $(\mathrm{cm})$ \\
$T\left({ }^{\circ} \mathrm{C}\right)$ & $(\mathrm{n})$ & & & Mean $\pm \mathrm{SE}$ & Mean $\pm \mathrm{SE}$ \\
\hline Cod $_{\mathrm{S}}$ & & & & & \\
5 & 13 & 13 & $\mathrm{Y}$ & $1.14 \pm 0.10$ & $5.22 \pm 0.19$ \\
8 & 10 & 9 & $\mathrm{Y}$ & $0.65 \pm 0.02$ & $4.13 \pm 0.04$ \\
12 & 13 & 8 & $\mathrm{Y}$ & $0.53 \pm 0.03$ & $3.99 \pm 0.06$ \\
12 & 8 & 9 & $\mathrm{Y}$ & $0.59 \pm 0.11$ & $3.96 \pm 0.21$ \\
15 & 14 & 9 & $\mathrm{Y}$ & $1.72 \pm 0.18$ & $5.58 \pm 0.31$ \\
$\mathrm{Cod}_{\mathrm{L}}$ & & & & & \\
5 & 16 & 13 & $\mathrm{~N}$ & $8.60 \pm 0.68$ & $9.51 \pm 0.24$ \\
8 & 15 & 10 & $\mathrm{~N}$ & $5.24 \pm 0.32$ & $8.11 \pm 0.15$ \\
8 & 8 & 11 & $\mathrm{~N}$ & $8.52 \pm 0.87$ & $9.57 \pm 0.33$ \\
12 & 13 & 10 & $\mathrm{~N}$ & $7.44 \pm 0.44$ & $8.90 \pm 0.17$ \\
12 & 6 & 11 & $\mathrm{~N}$ & $7.70 \pm 0.86$ & $9.29 \pm 0.35$ \\
15 & 17 & 11 & $\mathrm{Y}$ & $6.51 \pm 0.42$ & $9.45 \pm 0.21$ \\
$\mathrm{Haddock}^{2}$ & & & & & \\
8 & 11 & 11 & $\mathrm{Y}$ & $4.06 \pm 0.44$ & $7.19 \pm 0.29$ \\
8 & 6 & 10 & $\mathrm{Y}$ & $4.13 \pm 0.95$ & $6.91 \pm 0.56$ \\
12 & 6 & 10 & $\mathrm{Y}$ & $2.61 \pm 0.13$ & $6.22 \pm 0.12$ \\
12 & 10 & 11 & $\mathrm{Y}$ & $4.41 \pm 0.45$ & $7.24 \pm 0.27$ \\
& & & & & \\
\hline
\end{tabular}

Biochemical-based indicators of growth. Nucleic acid content was quantified according to Caldarone et al. (2001), with the following modifications for work with juvenile fish. Samples of muscle tissue $(\sim 1$ to $6 \mathrm{mg}$ freeze-dried weight) were removed from a $-80^{\circ} \mathrm{C}$ freezer, immediately freeze-dried $(>12 \mathrm{~h})$, weighed $( \pm 0.001 \mathrm{mg}$, Cahn microbalance $)$ and immersed in $300 \mu$ l buffered $1 \%$ sarcosil. The sample was then sonicated for $5 \mathrm{~s}$ (Fisher Sonic Dismembrator 60, Level 5), shaken for $0.5 \mathrm{~h}$ (Fisher Vortex Genie 2, Level 3), diluted with tris-EDTA buffer ( $\mathrm{pH} \mathrm{7.0)}$ to a volume of $1.5 \mathrm{ml}$, and centrifuged (11000 × g, $15 \mathrm{~min})$. The supernatant was removed and diluted to $0.1 \%$ sarcosil and the concentrations of RNA and DNA were estimated from the fluorescence in ethidium bromide before and after sequential treatment with RNase and DNase. Commercial preparations of $18 \mathrm{~s}$ plus 28s rRNA (Sigma) and ultra-pure highly polymerized calf thymus DNA were used as standards. The concentration of protein in the homogenate was measured spectrophotometrically (Cambridge Instruments 7520 Microplate Reader) using the protocol of Smith et al. (1985) adapted for a 96-well microplate format. Samples or standards plus reagents were incubated at $60^{\circ} \mathrm{C}$ for $1 \mathrm{~h}$ to allow for complete color development. A serial dilution of bovine serum albumin was used as a standard. RNA, DNA, and protein 
Table 2. Gadus morhua and Melanogrammus aeglefinus. Parameter estimates for 2 equations predicting growth $(G, \%$ weight $\left.\mathrm{d}^{-1}\right)$ from daily food consumption $\left(C, \%\right.$ weight $\left.\mathrm{d}^{-1}\right)$. Parameter estimates are provided for 1 of 2 equations: (T1) a 3-parameter non-linear function, or (T2) a 2-parameter linear function. These equations predict $G$ at food consumption rates between 0 (unfed) and $C_{\max }$ (mean $\pm \mathrm{SE}$ rate of food consumption by fish provided maximum food rations, $\mathrm{n}=2$ to 5 tanks for each species at each temperature, 3 fish per tank). na = not applicable

\begin{tabular}{|c|c|c|c|c|c|c|c|c|}
\hline \multirow[t]{2}{*}{ Species } & \multirow{2}{*}{$\begin{array}{c}T \\
\left({ }^{\circ} \mathrm{C}\right)\end{array}$} & \multirow{2}{*}{$\begin{array}{c}C_{\max } \\
\left(\% \mathrm{~d}^{-1}\right) \\
\text { Mean } \pm \text { SE }\end{array}$} & \multicolumn{6}{|c|}{ Parameter estimates } \\
\hline & & & Eq. & $\Phi$ & Mean \pm SE & Mean $\pm \mathrm{SE}$ & $\mathrm{n}$ & $\mathrm{R}^{2}$ \\
\hline \multirow[t]{4}{*}{$\operatorname{Cod}_{\mathrm{S}}$} & 5 & $5.8 \pm 0.3$ & (T1) & $1.61 \pm 0.55$ & $2.98 \pm 0.57$ & $0.31 \pm 0.13$ & 13 & 0.90 \\
\hline & 8 & $7.6 \pm 0.1$ & (T1) & $1.90 \pm 0.35$ & $3.69 \pm 0.40$ & $0.47 \pm 0.18$ & 10 & 0.97 \\
\hline & 12 & $13.0 \pm 0.1$ & (T2) & na & $-1.30 \pm 0.23$ & $0.39 \pm 0.04$ & 21 & 0.86 \\
\hline & 15 & $9.3 \pm 0.6$ & (T1) & $0.52 \pm 0.30$ & $2.06 \pm 0.37$ & $0.44 \pm 0.18$ & 13 & 0.84 \\
\hline \multirow{4}{*}{$\operatorname{Cod}_{\mathrm{L}}$} & 5 & $4.9 \pm 0.5$ & (T1) & $2.19 \pm 0.65$ & $2.86 \pm 0.62$ & $0.25 \pm 0.10$ & 16 & 0.95 \\
\hline & 8 & $6.3 \pm 0.5$ & (T1) & $1.21 \pm 0.20$ & $2.32 \pm 0.22$ & $0.42 \pm 0.10$ & 23 & 0.90 \\
\hline & 12 & $7.7 \pm 1.1$ & (T1) & $0.76 \pm 0.28$ & $2.68 \pm 0.31$ & $0.38 \pm 0.11$ & 19 & 0.87 \\
\hline & 15 & $6.7 \pm 0.2$ & (T1) & $0.44 \pm 0.41$ & $1.80 \pm 0.41$ & $0.33 \pm 0.18$ & 17 & 0.88 \\
\hline \multirow[t]{2}{*}{ Haddock } & 8 & $9.6 \pm 0.7$ & (T2) & na & $-0.90 \pm 0.11$ & $0.37 \pm 0.02$ & 17 & 0.94 \\
\hline & 12 & $10.5 \pm 1.2$ & (T2) & na & $-1.08 \pm 0.20$ & $0.34 \pm 0.03$ & 16 & 0.89 \\
\hline
\end{tabular}

concentration were calculated based upon the freezedried weight of the muscle sample.

In one trial, unfed haddock at $8^{\circ} \mathrm{C}$ were sampled (wet weight and SL measured and muscle dissected) at the beginning (Day 0), in the middle (Day 3), and at the end (Day 10) of the trial in an effort to assess the time

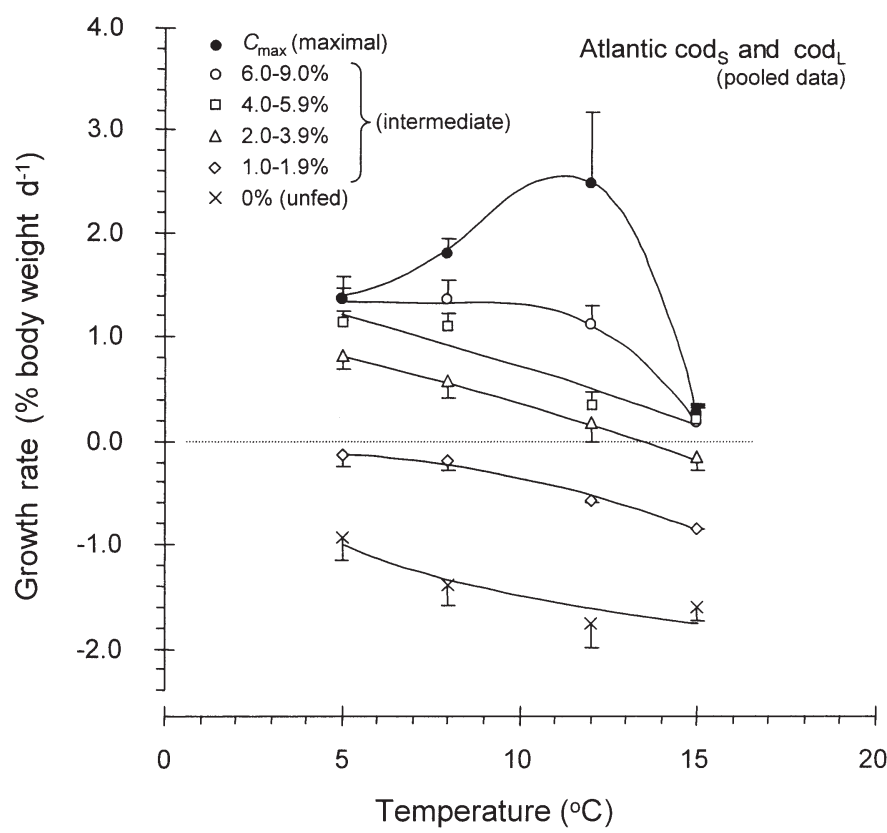

Fig. 1. Gadus morhua. Growth rate (\% body weight $\left.\mathrm{d}^{-1}\right)$ versus water temperature for age- 0 juvenile Atlantic cod (pooled data for $\operatorname{cod}_{\mathrm{S}}=$ mean $0.92 \mathrm{~g}, \operatorname{cod}_{\mathrm{L}}=$ mean $7.30 \mathrm{~g}$ wet weight). Growth rates of fish held at different rates of food consumption are shown. Daily rates of food consumption are expressed as percentage of fish body weight, and include unfed, intermediate, and maximal (ad libitum) levels. Intermediate ration levels were partitioned into 4 separate groups for visual clarity. Values $=$ mean $\pm \mathrm{SE}$ course of changes in white muscle RNA, DNA, and protein.

Statistics. Data collected in this study were analyzed via linear regression, multiple linear regression, and non-linear regression analyses, using SAS statistical software (SAS 1989). The significance level was set at $\mathrm{p} \leq 0.05$.

\section{RESULTS}

\section{Rates of food consumption and somatic growth}

The observed maximum food consumption rate $\left(C_{\max }\right)$ ranged from 4.9 to $13.0 \% \mathrm{~d}^{-1}$ and was highest for both species at $12{ }^{\circ} \mathrm{C}$ (Table 2). Values for weightspecific growth rate $(G)$ for $\operatorname{cod}_{\mathrm{S}}(\sim 0.92 \mathrm{~g}$ wet weight), $\operatorname{cod}_{\mathrm{L}}(\sim 7.33 \mathrm{~g}$ wet weight) and haddock $(\sim 3.80 \mathrm{~g}$ wet weight) ranged from -2.2 to $4.3,-2.4$ to 1.6 , and -1.6 to $3.8 \% \mathrm{~d}^{-1}$, respectively. Rates of $G$ varied with both water temperature and feeding level. For example, $G$ decreased at higher temperatures in unfed fish, whereas $G$ increased with temperature in fish feeding maximally between temperatures of 5 and $12{ }^{\circ} \mathrm{C}$ (Fig. 1). For each species, $G$ increased with increased daily feeding level and in most cases for $\operatorname{cod}_{S}$ and $\operatorname{cod}_{\mathrm{L}}$ appeared to approach a temperature-dependent asymptotic level at maximal rates of food consumption (Fig. 2). In most cases, the growth-feeding relationship for $\operatorname{cod}_{\mathrm{S}}$ and $\operatorname{cod}_{\mathrm{L}}$ at each temperature was described by a 3-parameter, asymptotic function:

$$
G \%(\mathrm{~d})^{-1}=\Phi-\mathrm{a}\left(\exp ^{(-C \times \mathrm{b})}\right)
$$

where $\Phi, \mathrm{a}$, and $\mathrm{b}$ are constants and $C=\% \mathrm{~d}^{-1}$ (Table 2). For haddock and $\operatorname{cod}_{\mathrm{S}}$ at $12{ }^{\circ} \mathrm{C}$, linear functions explained a similar proportion of the variability in 
$G$ with less variance around parameter estimates (Table 2). Values for $G$ of $\operatorname{cod}_{\mathrm{S}}$ and $\operatorname{cod}_{\mathrm{L}}$ were relatively low at all feeding levels at $15^{\circ} \mathrm{C}$ (Fig. 2).

The linear growth-feeding relationships for haddock at 8 and $12^{\circ} \mathrm{C}$ could be combined into a multiple linear regression including food consumption $(C)$ and temperature $(T)$ as independent variables:

$$
\begin{gathered}
\text { Haddock } G=-0.3( \pm 0.4)+35.1( \pm 2.0) C-0.07( \pm 0.04) T \\
\mathrm{n}=34, \mathrm{R}^{2}=0.914
\end{gathered}
$$

where mean $( \pm \mathrm{SE})$ parameter estimates are indicated. The addition of body size (wet weight) as an independent variable did not significantly increase the amount of variability explained by this regression.

Maintenance rations $\left(C_{\text {main }}\right)$, calculated using parameter estimates listed in Table 2 and solving for $G=0$, increased with temperature and were highest at $15^{\circ} \mathrm{C}$ in $\operatorname{cod}_{\mathrm{S}}$ (Table 3, Fig. 3). The difference between $C_{\text {main }}$ and observed $C_{\max }$ or the scope for growth (SfG) (Elliott 1975a), was greatest at $12^{\circ} \mathrm{C}$ and reduced at $15^{\circ} \mathrm{C}$, especially for $\operatorname{cod}_{\mathrm{L}}$ (Fig. 3).

\section{Growth efficiency}

Gross growth efficiency (GGE), calculated from Eq. (3) using observed $C$ and predicted $G$ ( $G$ from equations and parameter estimates listed in Table 2), was influenced by both temperature and the rate of food consumption (Fig. 2). Maximal GGE for the smaller cod was greatest at $8^{\circ} \mathrm{C}$, while that for the larger cod occurred at $5^{\circ} \mathrm{C}$ (Fig. 2, Table 3). GGE max $_{\text {ma }}$ tended to de-

Table 3. Gadus morhua and Melanogrammus aeglefinus. Predicted rates of food consumption $(C)$ and maximal gross growth efficiency $\left(\mathrm{GGE}_{\max }\right)$ at different temperatures for age- 0 juvenile cod and haddock. Maintenance consumption rates $\left(C_{\text {main }}\right)$, $\mathrm{GGE}_{\max }$, and the consumption rate at $\mathrm{GGE}_{\max }$ were calculated using equations in Table 2. Error estimates (SE) were equal to the difference between values calculated using the parameter

\begin{tabular}{|c|c|c|c|c|}
\hline \multirow[t]{2}{*}{$\begin{array}{l}\text { Species } \\
\text { (wet wt) }\end{array}$} & \multirow[t]{2}{*}{$T\left({ }^{\circ} \mathrm{C}\right)$} & \multicolumn{2}{|c|}{$\begin{array}{l}\text { Predicted rate of food } \\
\text { consumption }(C) \\
\left(\% \text { body weight } \mathrm{d}^{-1}\right)\end{array}$} & \multirow[t]{2}{*}{$\begin{array}{c}\mathrm{GGE}_{\max } \\
(\%)\end{array}$} \\
\hline & & $\begin{array}{c}C_{\text {main }} \\
\text { Mean } \pm \mathrm{SE}\end{array}$ & $\begin{array}{l}C \text { at } \mathrm{GGE}_{\max } \\
\text { Mean } \pm \mathrm{SE}\end{array}$ & \\
\hline $\begin{array}{l}\operatorname{Cod}_{\mathrm{S}} \\
(0.92 \mathrm{~g})\end{array}$ & $\begin{array}{r}5 \\
8 \\
12 \\
15\end{array}$ & $\begin{array}{l}1.9 \pm 0.8 \\
1.4 \pm 0.5 \\
3.3 \pm 1.0 \\
3.2 \pm 1.4\end{array}$ & $\begin{array}{r}4.9 \pm 2.0 \\
3.7 \pm 1.3 \\
13.0 \pm 0.1 \\
6.1 \pm 2.4\end{array}$ & $\begin{array}{r}20.0 \\
33.9 \\
28.6 \\
6.2\end{array}$ \\
\hline $\begin{array}{l}\operatorname{Cod}_{\mathrm{L}} \\
(7.33 \mathrm{~g})\end{array}$ & $\begin{array}{r}5 \\
8 \\
12 \\
15\end{array}$ & $\begin{array}{l}1.1 \pm 0.5 \\
1.5 \pm 0.4 \\
3.3 \pm 1.1 \\
4.2 \pm 2.3\end{array}$ & $\begin{array}{l}3.7 \pm 1.5 \\
3.9 \pm 1.0 \\
6.5 \pm 2.0 \\
6.7 \pm 2.0\end{array}$ & $\begin{array}{r}28.7 \\
19.5 \\
8.1 \\
3.6\end{array}$ \\
\hline $\begin{array}{l}\text { Haddock } \\
(3.80 \mathrm{~g})\end{array}$ & $\begin{array}{r}8 \\
12\end{array}$ & $\begin{array}{l}2.5 \pm 0.5 \\
2.8 \pm 1.9\end{array}$ & $\begin{array}{r}9.6 \pm 0.7 \\
10.5 \pm 1.2\end{array}$ & $\begin{array}{l}27.2 \\
23.7\end{array}$ \\
\hline
\end{tabular}
error $(+\mathrm{SE})$ estimates in those equations. $\mathrm{GGE}=\mathrm{G} / \mathrm{C}$

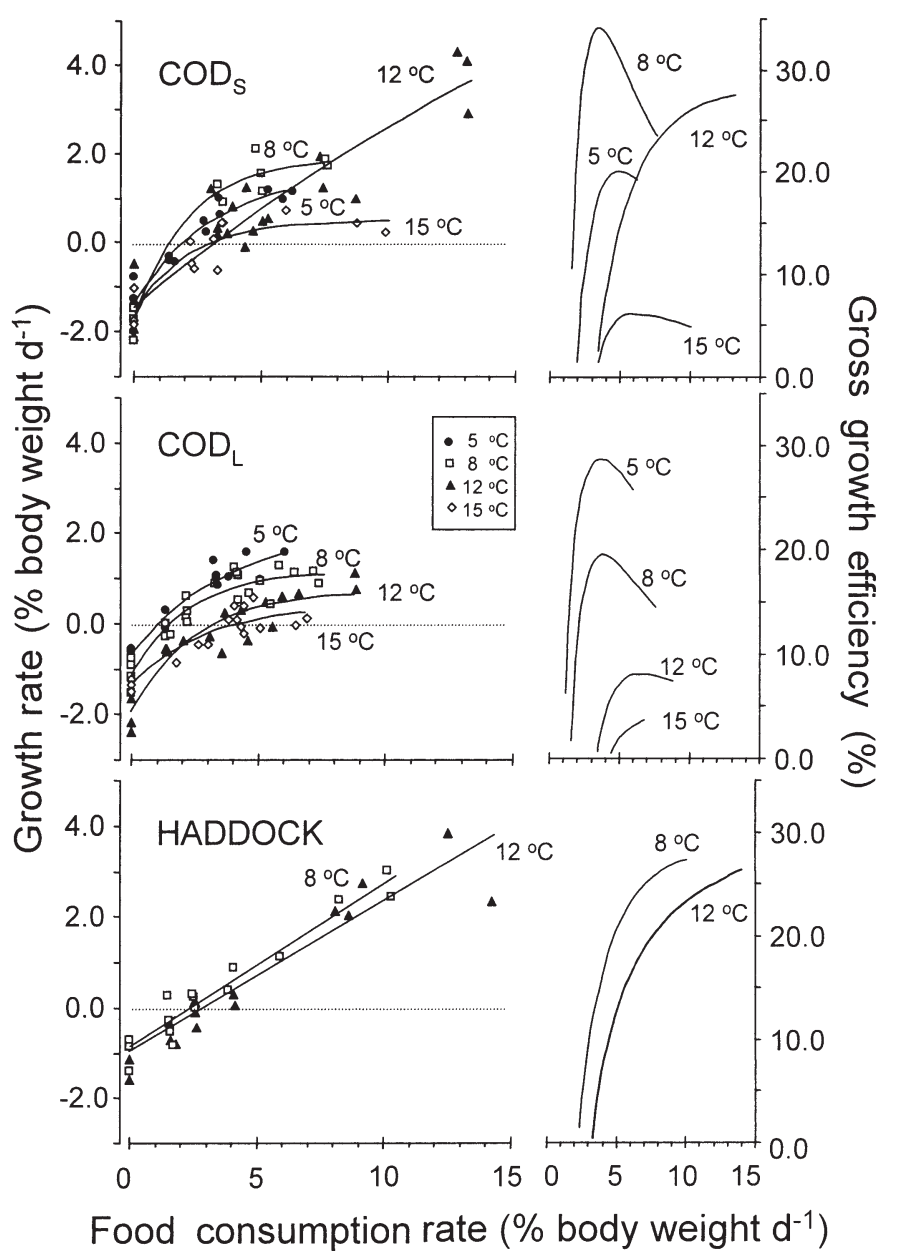

Fig. 2. Gadus morhua and Melanogrammus aeglefinus. Growth rate $\left(\%\right.$ body weight $\left.\mathrm{d}^{-1}\right)$ and gross growth efficiency (\%) versus food consumption rate ( $\%$ body weight $\left.\mathrm{d}^{-1}\right)$, for age-0 juvenile Atlantic cod and haddock. Data are shown for 2 size-classes of $\operatorname{cod}\left(\operatorname{cod}_{\mathrm{S}}=\right.$ mean $0.92 \mathrm{~g}, \operatorname{cod}_{\mathrm{L}}=$ mean $7.30 \mathrm{~g}$ wet weight $)$. Growth Crate regression lines are for the equations listed in Table 2

cline with temperature in both species with the highest values equal to $33.9 \%\left(8^{\circ} \mathrm{C}\right), 28.9 \%\left(5^{\circ} \mathrm{C}\right)$, and $27.2 \%$ $\left(8^{\circ} \mathrm{C}\right)$, for $\operatorname{cod}_{\mathrm{S}}, \operatorname{cod}_{\mathrm{L}}$, and haddock, respectively (Fig. 2, Table 3). GGE $_{\max }$ occurred at intermediate feeding levels at most temperatures in cod and at maximal feeding levels in haddock. The feeding level at GGE max increased with increasing temperature in $\operatorname{cod}_{\mathrm{L}}$ and haddock, but not in $\operatorname{cod}_{\mathrm{S}}$ (Fig. 2, Table 3). GGE of both cod groups at $15^{\circ} \mathrm{C}$ was relatively low at all ration levels compared to other temperatures with $\mathrm{GGE}_{\max }$ equal to 6.2 and $3.6 \%$, respectively (Fig. 2, Table 3).

\section{Biochemical-based indicators of growth}

Changes in the biochemical measures of white muscle of unfed haddock at $8^{\circ} \mathrm{C}$ with time indicated that 


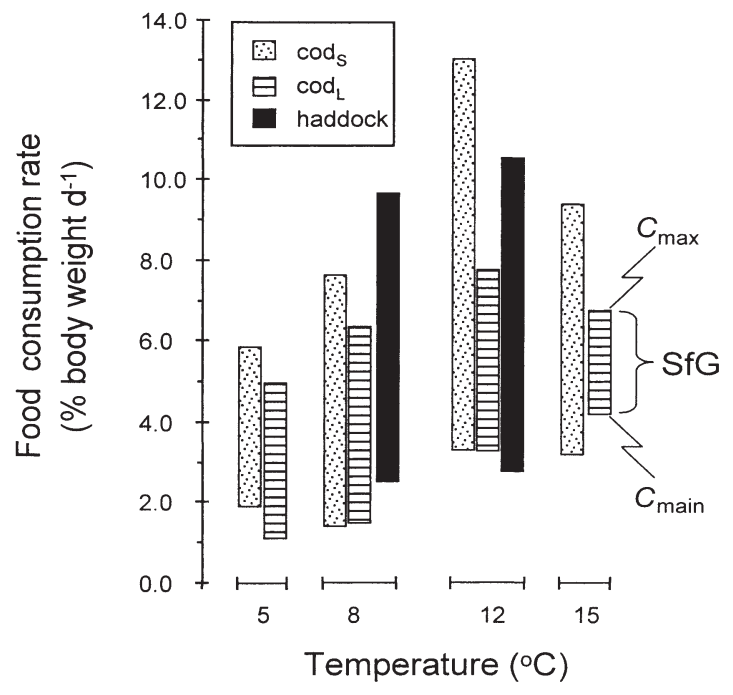

Fig. 3. Gadus morhua and Melanogrammus aeglefinus. Food consumption rate (\% body weight $\mathrm{d}^{-1}$ ) versus temperature for age-0 juvenile Atlantic $\operatorname{cod}_{\mathrm{S}}, \operatorname{cod}_{\mathrm{L}}$, and haddock. Maintenance $\left(C_{\text {main }}\right)$ and maximal $\left(C_{\max }\right)$ food consumption rates are indicated. Bars indicate the scope for growth $(\mathrm{SfG}=$ $\left.C_{\text {main }}-C_{\max }\right)$

nucleic acids (e.g. RNA:DNA, R:D) responded within $\sim 3 \mathrm{~d}$ to the cessation of feeding at this temperature, and changed little after an additional $7 \mathrm{~d}$ (Fig. 4). At temperatures between 5 and $12^{\circ} \mathrm{C}$, white muscle R:D in unfed fish (5.91 to 7.42 ) was nearly half (64\%) that of fish fed maximum rations (10.74 to 12.18) (Table 4, Fig. 4). Other biochemical measures including RNA: freeze-dried weight (R:W) and RNA:protein (R:P) also decreased with decreasing feeding level (values for unfed fish were $\sim 77 \%$ of those measured in fish feeding maximally) (Table 4 ). For both species at each temperature, linear regressions using R:D as an independent variable explained the most variability in juvenile $G$ (dependent variable) followed by R: $W$, R:P, and protein:freeze-dried weight (P: $W$ ) (Table 5).

Multiple linear regressions using R:D and water temperature $(T)$ as independent variables explained a significant portion of the variability in $G$ of cod and haddock:

$$
\begin{gathered}
\text { Cod } G=-7.14( \pm 0.79)+0.65( \pm 0.06) \\
\mathrm{R}: \mathrm{D}+0.23( \pm 0.04) T \\
\mathrm{n}=56, \mathrm{R}^{2}=0.716 \\
\text { Haddock } G=-6.05( \pm 1.15)+0.59( \pm 0.08) \\
\mathrm{R}: \mathrm{D}+0.16( \pm 0.08) T \\
\mathrm{n}=31, \mathrm{R}^{2}=0.637
\end{gathered}
$$

where mean $( \pm \mathrm{SE})$ parameter estimates are indicated for both equations. The addition of body size (wet weight) as a variable did not significantly increase the variability explained by either of these regressions, nor did the addition of R:P ( $p>0.10)$.
At $15^{\circ} \mathrm{C}$, values of white muscle R:D, R: $W$, and R:P in cod, were 60,52 , and $51 \%$ of the mean values of the 3 lower temperatures averaged across the 3 feeding levels (Table 4).

\section{DISCUSSION}

\section{Rates of food consumption and growth}

Maximum rates of food consumption $\left(C_{\max }\right)$ and growth $\left(G_{\max }\right)$ in marine fish are typically related allometrically to body size (Brett \& Groves 1979) and sizespecific rates in the present study are in line with those of previous studies on this species. For example, rates of $C_{\text {max }}$ in cod larvae, $0.90 \mathrm{~g}$ juveniles, $7.30 \mathrm{~g}$ juveniles, and $500 \mathrm{~g}$ adults have been measured to be $\sim 55,13.1$, 8.9, and $1.9 \% \mathrm{~d}^{-1}$, respectively (Edwards et al. 1972, see their Table 2; Karamushko \& Reshetnikov 1994, present study). The allometric scaling of $G_{\max }$ with body size has been quantified at a variety of temperatures by Björnsson \& Steinarsson (2002) for juvenile and adult cod and by Otterlei (2000) for young juveniles over a size range of 2 to $20 \mathrm{~g}$. In the present study, our value of $G_{\text {max }}$ for $\operatorname{cod}_{\mathrm{S}}(0.92 \mathrm{~g})$ at $8^{\circ} \mathrm{C}$ was $2.1 \% \mathrm{~d}^{-1}$, which agrees well with growth rates obtained in other laboratory studies using age-0 juvenile cod (Brown et al. 1989,

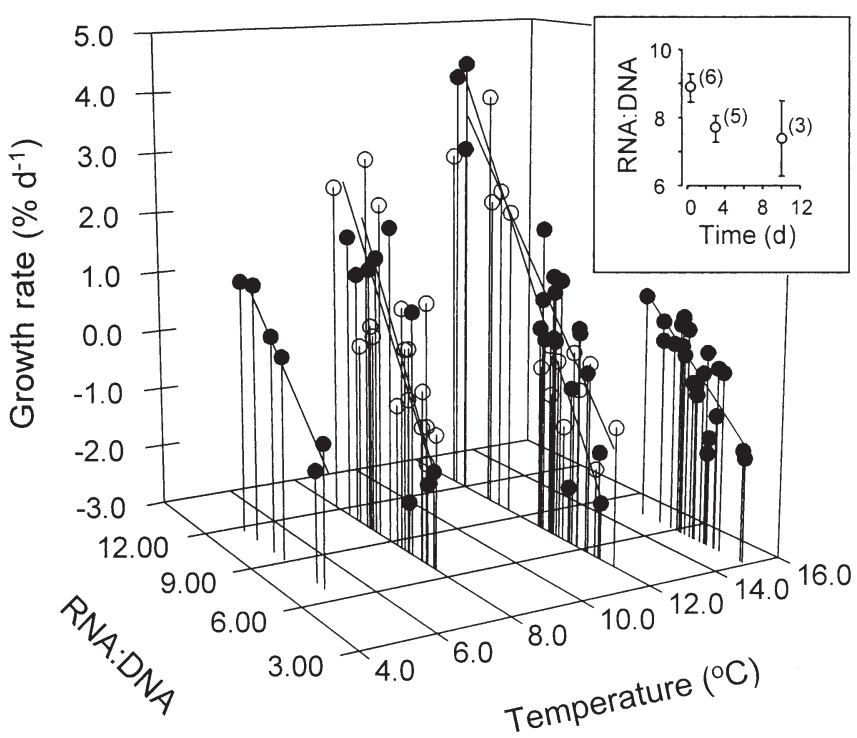

Fig. 4. Gadus morhua and Melanogrammus aeglefinus. RNA:DNA and growth rate data collected at $5,8,12$, and $15^{\circ} \mathrm{C}$ for $\operatorname{cod}(\mathrm{n}=56, \bullet)$ and at 8 and $12^{\circ} \mathrm{C}$ for haddock ( $\mathrm{n}=32$, ). Each datum equals the mean RNA:DNA and growth rate for the 3 fish in each tank. Linear regression equations and statistics are provided in Table 5. Insert: mean \pm SE RNA:DNA versus time since last feeding (d) at $8.0^{\circ} \mathrm{C}$ for 6.1 to $8.2 \mathrm{~cm}$ SL haddock. No. of fish sampled at each time is indicated in parentheses 
Table 4. Gadus morhua and Melanogrammus aeglefinus. Biochemical attributes of white muscle tissue collected from age-0 juvenile cod and haddock maintained at different levels of food consumption for 9 to $14 \mathrm{~d}$. Values are provided for RNA:DNA (R:D), RNA:freeze-dried weight (R:W), RNA:protein (R:P), and protein:freeze-dried weight (P:W). Ratio units = $\mu \mathrm{g}: \mu \mathrm{g}$. Three of the ratios (R:W, R:P, and P:W) were multiplied by 100 to express a percentage (\%) for ease of presentation. Number of tanks at each level of food consumption is indicated (n)

\begin{tabular}{|c|c|c|c|c|c|c|c|c|}
\hline \multirow[t]{2}{*}{ Ratio } & \multirow[t]{2}{*}{ Species } & \multirow[t]{2}{*}{$\begin{array}{c}T \\
\left({ }^{\circ} \mathrm{C}\right)\end{array}$} & Zero (ur & & \multicolumn{2}{|c|}{$\begin{array}{l}\text { Rate of daily food consumption } \\
\text { Intermediate }\end{array}$} & \multicolumn{2}{|c|}{ Maximum $\left(C_{\max }\right)$} \\
\hline & & & Mean $\pm \mathrm{SD}$ & $\mathrm{n}$ & Mean \pm SD & $\mathrm{n}$ & Mean \pm SD & $\mathrm{n}$ \\
\hline \multirow[t]{6}{*}{ R:D ( $\mu g: \mu g)$} & Cod & 5 & $7.05 \pm 0.31$ & 2 & $9.49 \pm 0.45$ & 2 & $11.29 \pm 0.58$ & 2 \\
\hline & & 8 & $7.24 \pm 0.67$ & 3 & $9.23 \pm 1.05$ & 4 & $11.45 \pm-$ & 1 \\
\hline & & 12 & $5.91 \pm 0.81$ & 4 & $7.25 \pm 0.73$ & 13 & $12.18 \pm 0.28$ & 3 \\
\hline & & 15 & $4.56 \pm 1.29$ & 6 & $5.43 \pm 0.84$ & 12 & $5.62 \pm 1.28$ & 5 \\
\hline & Haddock & 8 & $7.42 \pm 0.88$ & 4 & $8.51 \pm 1.33$ & 10 & $10.74 \pm 1.35$ & 3 \\
\hline & & 12 & $6.16 \pm 1.06$ & 3 & $7.36 \pm 1.79$ & 10 & $10.75 \pm 1.17$ & 2 \\
\hline \multirow{6}{*}{$\mathrm{R}: W(\%)$} & Cod & 5 & $1.46 \pm 0.10$ & 2 & $1.63 \pm 0.12$ & 2 & $1.92 \pm 0.13$ & 2 \\
\hline & & 8 & $1.40 \pm 0.22$ & 3 & $1.74 \pm 0.15$ & 4 & $1.89 \pm-$ & 1 \\
\hline & & 12 & $1.35 \pm 0.03$ & 4 & $1.42 \pm 0.10$ & 13 & $1.91 \pm 0.07$ & 3 \\
\hline & & 15 & $0.81 \pm 0.27$ & 6 & $0.81 \pm 0.17$ & 12 & $0.90 \pm 0.20$ & 5 \\
\hline & Haddock & 8 & $1.63 \pm 0.11$ & 3 & $1.92 \pm 0.29$ & 10 & $2.41 \pm 0.49$ & 3 \\
\hline & & 12 & $1.64 \pm 0.04$ & 2 & $1.76 \pm 0.20$ & 11 & $2.34 \pm 0.19$ & 2 \\
\hline \multirow[t]{6}{*}{ R:P (\%) } & Cod & 5 & $2.44 \pm 0.16$ & 2 & $2.75 \pm 0.16$ & 2 & $3.24 \pm 0.42$ & 2 \\
\hline & & 8 & $2.37 \pm 0.48$ & 3 & $2.83 \pm 0.44$ & 5 & $3.36 \pm-$ & 1 \\
\hline & & 12 & $2.21 \pm 0.13$ & 4 & $2.38 \pm 0.21$ & 12 & $3.04 \pm 0.25$ & 3 \\
\hline & & 15 & $1.39 \pm 0.47$ & 6 & $1.33 \pm 0.34$ & 12 & $1.44 \pm 0.24$ & 5 \\
\hline & Haddock & 8 & $2.70 \pm 0.23$ & 3 & $3.31 \pm 0.45$ & 10 & $4.15 \pm 1.01$ & 3 \\
\hline & & 12 & $2.52 \pm 0.05$ & 2 & $2.78 \pm 0.33$ & 11 & $3.65 \pm 0.34$ & 2 \\
\hline \multirow[t]{6}{*}{$\mathrm{P}: W(\%)$} & Cod & 5 & $60.05 \pm 0.17$ & 2 & $59.90 \pm 0.79$ & 2 & $59.51 \pm 3.51$ & 2 \\
\hline & & 8 & $62.56 \pm 6.07$ & 3 & $62.72 \pm 8.14$ & 5 & $62.93 \pm-$ & 1 \\
\hline & & 12 & $57.99 \pm 5.67$ & 4 & $61.01 \pm 2.93$ & 13 & $62.85 \pm 3.62$ & 3 \\
\hline & & 15 & $59.55 \pm 3.82$ & 6 & $61.10 \pm 3.47$ & 12 & $62.90 \pm 4.17$ & 5 \\
\hline & Haddock & 8 & $60.56 \pm 2.92$ & 3 & $58.17 \pm 3.58$ & 10 & $58.71 \pm 3.86$ & 3 \\
\hline & & 12 & $65.75 \pm 1.03$ & 2 & $64.15 \pm 3.98$ & 11 & $59.31 \pm 3.75$ & 2 \\
\hline
\end{tabular}

Folkvord \& Otterå 1993, Otterlei 2000, Purchase \& Brown 2000). For example, a $G_{\max }$ of $\sim 2.6 \% \mathrm{~d}^{-1}$ was observed for 0.9 to $9.2 \mathrm{~g}$ juvenile cod feeding maximally at $\sim 9.5^{\circ} \mathrm{C}$ (Folkvord \& Otterå 1993). $G_{\max }$ for age-0 juveniles appears to be $>2 \times G_{\max }$ of 2 and 3 yr old juvenile cod at similar temperatures (e.g. $\sim 300.0 \mathrm{~g}$ juveniles $\sim 0.9 \% \mathrm{~d}^{-1}$, Hawkins et al. 1985 , see their Fig. $8,10^{\circ} \mathrm{C}$ ).

Much less is known about maximal rates of food consumption and growth in haddock. The $G_{\max }$ for haddock at each temperature was greater than that for $\operatorname{cod}_{\mathrm{S}}$ and $\operatorname{cod}_{\mathrm{L}}$ at $8^{\circ} \mathrm{C}$, and $\sim 3 \times$ greater than that for $\operatorname{cod}_{\mathrm{L}}$ at $12^{\circ} \mathrm{C}$. Unfortunately, relatively few data exist (Jones 1978) to compare to our observed rates of $C_{\max }$ (9.6 to $10.5 \% \mathrm{~d}^{-1}$ ) and $G_{\max }\left(3.0\right.$ to $\left.3.1 \% \mathrm{~d}^{-1}\right)$ at 8 and $12^{\circ} \mathrm{C}$. Thus, the allometric relationship between fish size and rates of growth and food consumption in haddock remains largely unexplored. Similarly, comparisons of $C_{\max }$ and $G_{\max }$ rates measured in the laboratory and those estimated for field fish are hampered by a lack of data collected on rates of $C_{\max }$ or $G_{\max }$ for comparably sized early age-0 juvenile haddock (and cod) in the field. Additional field research targeting this somewhat elusive size range (see Lough \& Potter 1993) would permit a more detailed comparison of feeding and growth of laboratory and field fish.

\section{Shape of the growth-feeding relationship}

In the present study, the shape of the growth-feeding relationship varied between species and changed with temperature. At the lowest and highest temperatures, the relationship was non-linear and tended to reach a plateau in $\operatorname{cod}_{\mathrm{S}}$ and $\operatorname{cod}_{\mathrm{L}}$. At intermediate temperatures the relationship appeared more linear for haddock $\left(8\right.$ and $\left.12^{\circ} \mathrm{C}\right)$ and $\operatorname{cod}_{\mathrm{S}}\left(12^{\circ} \mathrm{C}\right)$, and no plateau was observed. The literature is equivocal with respect to the shape of the growth-feeding relationship in marine fish with both non-linear (asymptotic) (Elliott 1975b, Brett \& Groves 1979) and linear (Staples \& Nomura 1976, Malloy \& Targett 1994) relationships observed in other species. Similarly, studies on cod have indicated both non-linear (asymptotic) (Edwards et al. 1972, Brown et al. 1989) and linear (Jones \& Hislop 1978, Hawkins et al. 1985) growth-feeding relationships. Based upon a review of the literature on Atlantic cod, 
Jobling (1982) considered the relationship between growth and feeding to be linear.

The shape of the growth-feeding relationship has also been observed to change with temperature in other species including juvenile brown trout Salmo trutta (Elliott 1975b), and age-0 juvenile summer flounder Paralichthys dentatus (Malloy \& Targett 1994). Nevertheless, in a previous study using larger (100 g) juvenile cod, no differences were noted in the shape (linear relationship) among 4 different temperatures (Hawkins et al. 1985). Changes in the shape of the growth-feeding relationship with ontogeny (and/or size) and temperature indicate physiological changes with these factors, underscoring the importance of collecting basic physiological data on different life stages (and/or sizes) and at different temperatures for a species.

\section{$C_{\text {main }}$ scope for growth, and optimal temperature for growth}

The food consumption rate $\left(\% \mathrm{~d}^{-1}\right)$ required for maintenance of existing tissues, or maintenance con- sumption $\left(C_{\text {main }}, C\right.$ at $\left.G=0\right)$, tends to decrease with increasing fish size and increase with increasing temperature (Elliott 1975a,b, Brett \& Groves 1979, Hawkins et al. 1985). The decrease in $C_{\text {main }}$ with increasing fish size can be attributed to the allometric scaling of metabolism with body size and has been previously observed in larger juvenile cod by Jones \& Hislop (1978). Estimates of $C_{\text {main }}$ in the present study (1.1 to $4.2 \% \mathrm{~d}^{-1}$ ) were $\sim 4 \times$ greater than those $(0.3$ to $1.4 \% \mathrm{~d}^{-1}$ ) calculated for larger, $100 \mathrm{~g}$ juvenile cod at similar temperatures (Hawkins et al. 1985). The exponential increase in $C_{\text {main }}$ with temperature in the present study mirrors the increase in routine metabolism with temperature measured for similarly sized juvenile cod between 4.5 and $15.5^{\circ} \mathrm{C}$ (Peck et al. 2003). An exponential increase in $C_{\text {main }}$ with temperature has also been observed for larger (100 g) juvenile cod studied at $7,10,15$, and $18^{\circ} \mathrm{C}$ (Hawkins et al. 1985). The range of consumption rates greater than $C_{\text {main, }}$ or the scope for growth $\left(\mathrm{SfG}=C_{\max }-C_{\text {main }}\right.$ ) also tended to increase with temperature, being greatest at $12^{\circ} \mathrm{C}$ for $\operatorname{cod}_{\mathrm{S}}$ and haddock, and at $8^{\circ} \mathrm{C}$ for $\operatorname{cod}_{\mathrm{L}}$. SfG was greatly reduced at $15^{\circ} \mathrm{C}$ for both cod size-classes (Fig. 3).

Table 5. Gadus morhua and Melanogrammus aeglefinus. Parameter estimates (a and b) and regression statistics for the equation $G=\mathrm{a}+\mathrm{b}(\mathrm{X})$, estimating growth $\left(G, \%\right.$ body weight $\left.\mathrm{d}^{-1}\right)$ from various biochemical attributes $(\mathrm{X}, \mu \mathrm{g}: \mu \mathrm{g}$ or \%) of white muscle tissue of juvenile Atlantic cod and haddock. Biochemical attributes: RNA:DNA (R:D), RNA:freeze-dried weight (R: $W$ ), RNA:protein $(\mathrm{R}: \mathrm{P})$, and protein:freeze-dried weight $(\mathrm{P}: W)$

\begin{tabular}{|c|c|c|c|c|c|c|c|}
\hline $\begin{array}{l}\text { Biochemical } \\
\text { Attribute (X) }\end{array}$ & Species & $\begin{array}{c}T \\
\left({ }^{\circ} \mathrm{C}\right)\end{array}$ & $\begin{array}{c}\text { Parameter est } \\
\text { a } \\
\text { Mean } \pm \text { SE }\end{array}$ & $\begin{array}{c}G=\mathrm{a}+\mathrm{b}(\mathrm{X}) \\
\mathrm{b} \\
\text { Mean } \pm \mathrm{SE}\end{array}$ & $\mathrm{n}$ & $\begin{array}{c}\text { Statistics } \\
\mathrm{R}^{2}\end{array}$ & $\mathrm{p}$ \\
\hline \multirow[t]{2}{*}{$\mathrm{R}: \mathrm{D}(\mu \mathrm{g}: \mu \mathrm{g})$} & Cod & $\begin{array}{r}5 \\
8 \\
12 \\
15\end{array}$ & $\begin{array}{l}-4.41 \pm 0.67 \\
-6.25 \pm 2.18 \\
-4.80 \pm 0.73 \\
-2.66 \pm 0.50\end{array}$ & $\begin{array}{l}0.49 \pm 0.07 \\
0.74 \pm 0.24 \\
0.72 \pm 0.09 \\
0.46 \pm 0.09\end{array}$ & $\begin{array}{r}6 \\
8 \\
20 \\
23\end{array}$ & $\begin{array}{l}0.921 \\
0.576 \\
0.774 \\
0.565\end{array}$ & $\begin{aligned} & 0.002 \\
& 0.018 \\
< & 0.001 \\
< & 0.001\end{aligned}$ \\
\hline & Haddock & $\begin{array}{r}8 \\
12\end{array}$ & $\begin{array}{l}-4.31 \pm 1.36 \\
-4.44 \pm 0.77\end{array}$ & $\begin{array}{l}0.54 \pm 0.15 \\
0.63 \pm 0.09\end{array}$ & $\begin{array}{l}17 \\
15\end{array}$ & $\begin{array}{l}0.444 \\
0.774\end{array}$ & $\begin{array}{l}0.004 \\
0.001\end{array}$ \\
\hline \multirow[t]{2}{*}{$\mathrm{R}: W(\%)$} & Cod & $\begin{array}{r}5 \\
8 \\
12 \\
15\end{array}$ & $\begin{array}{l}-6.21 \pm 1.78 \\
-5.80 \pm 2.72 \\
-9.29 \pm 1.78 \\
-1.72 \pm 0.57\end{array}$ & $\begin{array}{l}3.83 \pm 1.06 \\
3.79 \pm 1.61 \\
6.77 \pm 1.19 \\
1.12 \pm 0.42\end{array}$ & $\begin{array}{r}6 \\
9 \\
20 \\
23\end{array}$ & $\begin{array}{l}0.765 \\
0.409 \\
0.642 \\
0.232\end{array}$ & $\begin{array}{r}0.023 \\
0.046 \\
<0.001 \\
0.016\end{array}$ \\
\hline & Haddock & $\begin{array}{r}8 \\
12\end{array}$ & $\begin{array}{l}-3.37 \pm 1.40 \\
-7.74 \pm 1.96\end{array}$ & $\begin{array}{l}1.95 \pm 0.70 \\
4.56 \pm 1.06\end{array}$ & $\begin{array}{l}16 \\
15\end{array}$ & $\begin{array}{l}0.355 \\
0.586\end{array}$ & $\begin{array}{r}0.015 \\
<0.001\end{array}$ \\
\hline \multirow[t]{2}{*}{$\mathrm{R}: \mathrm{P}(\%)$} & Cod & $\begin{array}{r}5 \\
8 \\
12 \\
15\end{array}$ & $\begin{array}{l}-5.34 \pm 1.84 \\
-4.19 \pm 2.14 \\
-8.60 \pm 2.05 \\
-1.72 \pm 0.57\end{array}$ & $\begin{array}{l}1.96 \pm 0.65 \\
1.67 \pm 1.06 \\
3.82 \pm 0.83 \\
1.12 \pm 0.42\end{array}$ & $\begin{array}{r}6 \\
8 \\
19 \\
23\end{array}$ & $\begin{array}{l}0.696 \\
0.261 \\
0.539 \\
0.271\end{array}$ & $\begin{array}{r}0.039 \\
0.159 \\
<0.001 \\
0.016\end{array}$ \\
\hline & Haddock & $\begin{array}{r}8 \\
12\end{array}$ & $\begin{array}{l}-3.35 \pm 1.29 \\
-7.27 \pm 3.03\end{array}$ & $\begin{array}{l}1.13 \pm 0.38 \\
2.74 \pm 0.70\end{array}$ & $\begin{array}{l}16 \\
15\end{array}$ & $\begin{array}{l}0.389 \\
0.539\end{array}$ & $\begin{array}{l}0.010 \\
0.002\end{array}$ \\
\hline \multirow[t]{2}{*}{$\mathrm{P}: W(\%)$} & Cod & $\begin{array}{r}5 \\
8 \\
12 \\
15\end{array}$ & $\begin{aligned} 5.95 & \pm 17.98 \\
-0.11 & \pm 5.89 \\
-10.45 & \pm 6.19 \\
-5.81 & \pm 2.50\end{aligned}$ & $\begin{array}{r}-0.10 \pm 0.30 \\
0.01 \pm 0.09 \\
0.19 \pm 0.10 \\
0.09 \pm 0.04\end{array}$ & $\begin{array}{r}6 \\
9 \\
20 \\
23\end{array}$ & $\begin{array}{l}0.025 \\
0.001 \\
0.163 \\
0.184\end{array}$ & $\begin{array}{l}0.764 \\
0.916 \\
0.087 \\
0.041\end{array}$ \\
\hline & Haddock & $\begin{array}{r}8 \\
12\end{array}$ & $\begin{array}{l}5.10 \pm 5.63 \\
5.87 \pm 7.19\end{array}$ & $\begin{array}{l}-0.08 \pm 0.10 \\
-0.08 \pm 0.11\end{array}$ & $\begin{array}{l}16 \\
15\end{array}$ & $\begin{array}{l}0.047 \\
0.040\end{array}$ & $\begin{array}{l}0.421 \\
0.473\end{array}$ \\
\hline
\end{tabular}


The growth dynamics of poikilotherms are, to a great extent, dictated by temperature. Consequently, a large body of research has focused on identifying the optimal temperature for growth in Atlantic cod. Results of a gastric evacuation study by Tyler (1970) were the first to suggest that the optimal temperature for growth in Atlantic cod was below $15^{\circ} \mathrm{C}$. Subsequently, these results have been confirmed by a number of growthfeeding studies which indicated an optimum temperature for growth $\left(G_{\max }\right)$ between 12 and $15^{\circ} \mathrm{C}$ for YOY Atlantic cod (Otterlei 2000, Björnsson \& Steinarsson 2002 , the present study). Results of the present study in which YOY growth was maximal for $\operatorname{cod}_{\mathrm{S}}$ at $12^{\circ} \mathrm{C}$ (and was relatively diminished in $\operatorname{cod}_{\mathrm{S}}$ and $\operatorname{cod}_{\mathrm{L}}$ at $15^{\circ} \mathrm{C}$ ) agree with the previous growth studies. However, it should be kept in mind that the 'optimum' temperature for growth of juvenile cod may likely be lower than $12^{\circ} \mathrm{C}$ in the wild due to food limitation at such high temperatures (Buckley et al. unpubl. data). At the present time, a discussion of the temperature optimum for growth in age-0 juvenile haddock is premature, although changes in growth rates and growth efficiencies (discussed below) for haddock between 8 and $12^{\circ} \mathrm{C}$ were similar to those found for cod.

\section{Gross growth efficiency}

The ranges in $\mathrm{GGE}_{\max }$ values for $\operatorname{cod}_{\mathrm{S}}$ and haddock at 8 and $12^{\circ} \mathrm{C}(23.7$ to $33.9 \%)$, and for $\operatorname{cod}_{\mathrm{L}}$ at 5 and $8^{\circ} \mathrm{C}(19.5$ to $28.7 \%)$ in this study agree well with the ranges in GGE obtained in other young juvenile fish including: $\sim 27$ to $30 \%$ for 6 to $10 \mathrm{~cm}$ bluefish Pomatomus saltatrix (Buckel et al. 1995), 22 to $35 \%$, and 29 to $31 \%$ for 4 to $8 \mathrm{~cm}$ plaice Pleuronectes platessa, and European flounder Platichthys flesus, respectively (Fonds et al. 1992). Of the various factors influencing GGE, feeding level, water temperature, and fish size are among the most important (Elliott 1975b). For example, GGE was greatly affected by ration level, with $\mathrm{GGE}_{\max }$ occurring at intermediate levels of food consumption at each temperature for cod (except $\operatorname{cod}_{\mathrm{S}}$ at $12^{\circ} \mathrm{C}$ ) due to the non-linear (asymptotic) growth-feeding relationship observed in this study. GGE max $_{\text {mas }}$ also observed at intermediate ration levels for larger (500 g wet weight) Atlantic cod by Edwards et al. (1972), and in any species where the growth-feeding relationship is observed to be asymptotic (e.g. Elliott 1975b, Brett \& Groves 1979). Our data indicate that $G G E_{\max }$ for $\operatorname{cod}_{S}$ and $\operatorname{cod}_{\mathrm{L}}$ occurs at mean feeding rates of $\sim 75$ and $80 \%$ of maximal consumption, respectively. These percentages are in close agreement with that (80\%) found by Elliott (1975b) for brown trout. This is in contrast, however, to $\mathrm{GGE}_{\max }$ in juvenile haddock, which occurred at maximal levels of food consumption (similar to that of $\operatorname{cod}_{\mathrm{S}}$ at $12^{\circ} \mathrm{C}$ ) due to the linear growthfeeding relationship.

GGE $_{\max }$ increased with decreasing temperature in $\operatorname{cod}_{\mathrm{S}}$, haddock, and most markedly in $\operatorname{cod}_{\mathrm{L}}$. The trend of increasing GGE $_{\max }$ with decreasing temperature has been previously observed by other researchers working on Atlantic cod age-0 juveniles (Brown et al. 1989) and larger juveniles (Hawkins et al. 1985), and seems to be an adaptive physiological characteristic of this predominantly cold-water species.

\section{Biochemical-based indicators of growth}

Results of the present study indicate that 1 biochemical-based indicator of growth, the R:D, can be used to predict growth and/or recent feeding level of age-0 juvenile cod and haddock at each of the temperatures examined. R:D explained the most variability in rates of $G$ of cod and haddock, followed by R: $W$ and R:P, with white muscle protein content $(\mathrm{P}: W)$ largely unrelated to short-term growth. Measurement of white muscle R:D, when combined with temperature in a multiple linear regression, explained a significant percentage of the variability in $G$ for age-0 juvenile cod $\left(\mathrm{R}^{2}=0.716\right)$ and haddock $\left(\mathrm{R}^{2}=0.637\right)$. Our findings are similar to those of other investigations measuring concentrations of nucleic acids in early (larval and YOY) stages of marine fish (e.g. Buckley 1984, Write \& Martin 1985, Malloy \& Targett 1994, Rooker \& Holt 1996, Kuropat et al. 2002). The response time of R:D to changes in feeding regime $(\sim 3 \mathrm{~d}$, Fig. 4$)$ is similar to that measured in other studies including $5 \mathrm{~d}$ in larger juvenile cod (Foster et al. 1993) and $1 \mathrm{~d}$ for early juvenile summer flounder (Malloy \& Target 1994).

Results of the present study indicate that the R:D of white muscle tissue was a good indicator of recent growth in Atlantic cod and haddock at body sizes attained by fish undergoing habitat transition (settlement). At the present time, our laboratory results may be used as a coarse indicator of recent growth in field fish. For example, setting $G$ equal to zero and solving for R:D in Eqs. (6) \& (7) yields:

$$
\begin{array}{r}
\text { Cod R: } \mathrm{D}_{\text {main }}=11.137-0.436(T), \\
T=5 \text { to } 15^{\circ} \mathrm{C} \\
\text { Haddock R: } \mathrm{D}_{\text {main }}=10.246-0.268(T), \\
T=8 \text { to } 12^{\circ} \mathrm{C}
\end{array}
$$

where $R: D_{\text {main }}$ equals the $R: D$ at zero growth. These equations provide temperature-specific R:D values for age-0 juvenile cod and haddock delineating fish that, in the short term, were likely feeding and growing well from those which were likely feeding and growing poorly. 


\section{Summary}

The growth rate of fish during the first year of life and its relationship to survival is a prominent feature in most hypotheses attempting to explain recruitment variability in marine fish. The confluence of 2 factors, feeding level and temperature, plays a dominant role in determining fish growth rate (Brett \& Groves 1979) which, during the age- 0 juvenile period, has been positively correlated to year-class success in Atlantic cod (Campana 1996). The latter correlation provided the impetus for the present laboratory study, as it underscored the importance of (1) understanding how various factors affect growth, and (2) obtaining accurate growth estimates of age-0 juvenile cod and haddock.

With regard to our first research objective, results of this study indicated that growth rates were markedly affected by feeding level with the observed range in growth rates as great as $6.5 \% \mathrm{~d}^{-1}$ separating fish that were unfed from those that were maximally feeding. By defining the shape of the growth-feeding relationship at different temperatures, we estimated how temperature influenced weight loss in unfed fish (endogenous metabolism), the daily rate $\left(C_{\text {main }}\right)$ and range (scope for growth) of food consumption required to sustain positive growth, and the gross growth efficiency at which that growth occurs. These estimates should aid in the formulation of hypotheses regarding age-0 juvenile growth and survival on Georges Bank. For example, the marked decline in $\mathrm{GGE}_{\max }$ with temperature could serve to decrease the relative survival potential of juveniles undergoing the habitat transition later in the year (at warmer temperatures) on Georges Bank. With regard to our second research objective, results of this study indicate that measurements of white muscle nucleic acids can be used as a biochemical-based indicator of growth. Growth rates of age- 0 juveniles in the field may be estimated directly from measurements of white muscle R:D and temperature. With growth estimates of field-caught juveniles in hand, it may be possible to, among other things, identify factors varying spatially (e.g. related to habitat suitability; Kuropat et al. 2002) that affect growth and survival, generate a relative biochemical-based index of year-class status, and/or buttress modeling efforts aimed at understanding the ecology and recruitment processes of Atlantic cod and haddock.

Acknowledgements. We are indebted to the following people for their help with data collection: J. St. Onge-Burns, J. Hermsen, R. Katersky, A. Lapolla, S. Menezes, and T. Smith. We would like to thank J. Heltshe for statistical advice. We are grateful to the employees of the NOAA NMFS Narragansett Laboratory for the use of aquarium and laboratory facilities. This research was supported by NOAA/University of Rhode Island Cooperative Marine Education and research grant \#NA77FE0494.

\section{LITERATURE CITED}

Björnsson B, Steinarsson A (2002) The food-unlimited growth rate of Atlantic cod (Gadus morhua). Can J Fish Aquat Sci 59:494-502

Brett JR, Groves TDD (1979) Physiological energetics. In: Hoar WS, Randall DJ, Brett JR (eds) Fish physiology, Vol VIII. Academic Press, New York, p 279-352

Brown JA, Pepin P, Methven DA, Somerton DC (1989) The feeding, growth and behaviour of juvenile cod, Gadus morhua L., in cold environments. J Fish Biol 35:373-380

Buckel JA, Steinberg ND, Conover DO (1995) Effects of temperature, salinity, and fish size on growth and consumption of juvenile blue fish. J Fish Biol 47:696-706

Buckley LJ (1984) RNA-DNA ratio: an index of larval growth in the sea. Mar Biol 80:291-298

Caldarone EM, Wagner M, St Onge-Burns J, Buckley LJ (2001) Protocol and guide for estimating nucleic acids in larval fish using a fluorescence microplate reader. Northeast Fish Sci Cent Ref Doc 01-11:11-22, available at: www.nefscnmfsgov/nefsc/publicatins/crd/crd0111/0111.htm

Campana SE (1996) Year-class strength and growth rate in young Atlantic cod Gadus morhua. Mar Ecol Prog Ser 135: $21-26$

Campana SE, Frank KT, Hurley PCF, Koeller PA, Page FH, Smith PC (1989) Survival and abundance of young Atlantic cod (Gadus morhua) and haddock (Melanogrammus aeglefinus) as indicators of year-class strength. Can J Fish Aquat Sci 46(Suppl. 1):171-182

Clark DS, Green JM (1990) Activity and movement patterns of juvenile Atlantic cod, Gadus morhua, in Conception Bay, Newfoundland, as determined by sonic telemetry. Can J Zool 68:1434-1442

Edwards RRC, Finlayson DM, Steele JH (1972) An experimental study of the oxygen consumption, growth, and metabolism of the cod (Gadus morhua L.). J Exp Mar Biol Ecol 8:299-309

Elliott JM (1975a) The growth rate of brown trout (Salmo trutta L.) fed on maximal rations. J Anim Ecol 44:805-822

Elliott JM (1975b) The growth rate of brown trout (Salmo trutta L.) fed on reduced rations. J Anim Ecol 44:823-842

Fahay MP, Berrien PL, Johnson DL, Morse WW (1999) Essential fish habitat source document: Atlantic cod, Gadus morhua, life history and habitat characteristics. US NOAA Tech Memo National Marine Fisheries Service Northeast Region, Document No. 124, Woods Hole, MA, p 1-41

Folkvord A, Otterå H (1993) Effects of initial size distribution, day length, and feeding frequency on growth, survival, and cannibalism in juvenile Atlantic cod (Gadus morhua L.). Aquaculture 114:243-260

Fonds M, Cronie R, Vethaak AD, Van Der Puyl P (1992) Metabolism, food consumption and growth of plaice (Pleuronectes platessa) and flounder (Platichthys flesus) in relation to fish size and temperature. Neth J Sea Res 29: 127-143

Foster GD, Houlihan DF, Hall SJ (1993) Effects of nutritional regime on correlates of growth rate in juvenile Atlantic cod (Gadus morhua): comparison of morphological and biochemical measurements. Can J Fish Aquat Sci 50: $502-512$

Hawkins AD, Soofiani NM, Smith GW (1985) Growth and feeding of juvenile cod (Gadus morhua L.). J Cons Perm Int Explor Mer 42:11-32

Jobling M (1982) Food and growth relationships of the cod, Gadus morhua L., with special reference to Balsfjorden, north Norway. J Fish Biol 21:357-371

Jones R (1978) Estimates of the food consumption of haddock 
(Melanogrammus aeglefinus) and cod (Gadus morhua). J Cons Perm Int Explor Mer 38:18-27

Jones R, Hislop JRG (1978) Further observations on the relation between food intake and growth and gadoids in captivity. J Cons Perm Int Explor Mer 38:244-251

Karamushko OV, Reshetnikov YuS (1994) Daily rations of larval capelin, Mallotus villosus villosus, and cod, Gadus morhua morhua, in the Barents and Norwegian seas. J Ichthyol 34:48-57

Kuropat C, Mercaldo-Allen R, Caldarone E, Goldberg R, Phelan B, Thurberg F (2002) Evaluation of RNA concentration as an indicator of growth in young-of-the-year winter flounder Pseudopleronectes americanus and tautog Tautoga onitis. Mar Ecol Prog Ser 230:265-274

Lough RG, Potter DC (1993) Vertical distribution patterns and diel migrations of larval and juvenile haddock Melanogrammus aeglefinus and Atlantic cod Gadus morhua on Georges Bank. Fish Bull 91:281-303

Malloy KD, Targett TE (1994) Effects of ration limitation and low temperature on growth, biochemical condition, and survival of juvenile summer flounder from two Atlantic coast nurseries. Trans Am Fish Soc 123:182-193

Otterlei E (2000) Temperature- and size-dependent growth of larval and early juvenile Atlantic cod (Gadus morhua). $\mathrm{PhD}$ thesis. University of Bergen

Peck MA, Buckley LJ, Bengtson DA (2003) The effects of body size and temperature on energy losses due to routine and feeding metabolism in early juvenile Atlantic cod (Gadus morhua). Can J Fish Aquat Sci (in press)

Editorial responsibility: Kenneth Sherman (Contributing Editor), Narragansett, Rhode Island, USA
Purchase CF, Brown JA (2000) Interpopulation differences in growth rates and food conversion efficiencies of young Grand Banks and Gulf of Maine Atlantic cod (Gadus morhua). Can J Fish Aquat Sci 57:2223-2229

Rooker JR, Holt GJ (1996) Application of RNA:DNA ratios to evaluate the condition and growth of larval and juvenile red drum (Sciaenops ocellatus). Mar Freshw Res 47: 283-290

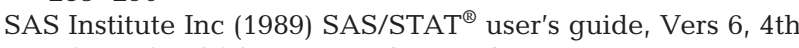
edn, Vol 2. SAS Institute, Cary, NC

Smith PK, Krohn RI, Hermanson GT, Mallia AK and 6 others (1985) Measurement of protein using bicinchoninic acid. Anal Biochem 150:76-85

Staples DJ, Nomura M (1976) Influence of body size and food ration on the energy budget of rainbow trout, Salmo gairdneri Richardson. J Fish Biol 9:29-43

Tupper M, Boutilier RG (1995) Size and priority at settlement determine growth and competitive success of newly settled Atlantic cod. Mar Ecol Prog Ser 118:295-300

Tyler AV (1970) Rates of gastric emptying in young cod. J Fish Res Board Can 27:1177-1189

Werner FE, Murawski S, Brander K (1999) Report of the workshop on ocean climate of the NW Atlantic during the 1960s and 1970s and consequences for gadoid populations. ICES Rapport des Recherches Collectives No 234, ICES, Copenhagen

Write DA, Martin FD (1985) The effect of starvation on RNA:DNA ratios and growth of larval striped bass, Morone saxatilis. J Fish Biol 27:479-485

Submitted: June 30, 2002; Accepted: November 26, 2002 Proofs received from author(s): March 21, 2003 